\title{
BRAND INTERNAL COMMUNICATIONS CULTURE (BICCU) KOTA MALANG
}

\author{
Sri Widayati \\ Rambu Naha \\ Program Studi Ilmu Komunikasi FISIP Universitas Merdeka Malang \\ Email : sriwidayati@unmer.ac.id
}

\begin{abstract}
Malang is a city that has a very heterogeneous population, because immigrants not only came from the city on the island of Java, but from outside of Java Island. Many impacts would arise as a result of the influx of immigrants from all parts of the ground water. The negative impact is most likely to occur is the cultural frictions due to different understandings. Multicultural education that had been made by various parties apparently not able to reduce the cultural misunderstandings. Especially during the activities undertaken to harmonize inter-ethnic conducted by various social organizations partially, has not been well integrated and focused, therefore, the government should be able to make such programs have become a government program ongoing to establish Brand Internal Communications Culture (BICCU).

The future is expected BICCU able to form a positive image of Malang as the City Multi ethnic harmonious and hamonis. This activity should be done in an integrated manner by all areas of the City Government of Malang who continue to coordinate with the social institutions, which is already capable of conducting union of multiculture significantly.
\end{abstract}

Keywords: Internal communication culture, education multiculture

\begin{abstract}
Abstrak
Kota Malang merupakan kota yang sudah sangat heterogen penduduknya, sebab pendatang tidak hanya datang dari Kota di dalam Pulau Jawa melainkan dari luar Pulau Jawa juga. Berbagai dampak tentunya muncul akibat dari membanjirnya pendatang dari seluruh penjuru tanah air tersebut. Dampak negatif yang paling mungkin untuk terjadi adalah terjadinya gesekan-gesekan budaya akibat perbedaan pemahaman. Pendidikan multikultural yang selama ini sudah dilakukan oleh berbagai pihak ternyata belum mampu mengurangi kesalahpahaman budaya tersebut. Apalagi selama ini kegiatan-kegiatan yang dilakukan untuk menyamakan persepsi antar etnis ini dilakukan oleh berbagai organisasi sosial secara parsial, belum terintegrasi secara baik dan terarah, oleh karenanya pemerintah harus mampu membuat program-program semacam ini menjadi satu program pemerintah yang berkesinambungan untuk membentuk Brand Internal Communications Culture (BICCU). Ke depannya diharapkan BICCU mampu membentuk citra positif Kota Malang sebagai Kota Multi etnis yang serasi, selaras dan hamonis. Kegiatan ini harus dilakukan secara terintegrasi oleh semua bidang di Pemerintahan Kota Malang yang terus berkoordinasi dengan lembaga-lembaga sosial yang selama ini sudah mampu menyelenggarakan kegiatan penyatuan multiculture secara nyata.
\end{abstract}

Kata kunci: Budaya Komunikasi Internal, Pendidikan Multikultural 


\section{PENDAHULUAN}

Letak geografis Kota Malang yang berada di wilayah pegunungan yang berudara sejuk dan biaya hidup yang tidak terlalu mahal menjadikan banyak orang berkeinginan untuk tinggal di Malang.Banyaknya pendatang dari segala penjuru daerah di Indonesia tentunya memberikan dampak yang beragam, baik positif maupun negatif. Keunikan masingmasing daerah yang menjadi identitas budaya tersebut tentunya memberikan dampak yang positif bagi Kota Malang dalam hal peningkatan daya tarik serta menunjukan ciri khas tertentu sebagai Kota Multikultural. Tetapi pada sisi yang lain keberagaman ini jika dipersatukan tanpa adanya pemahaman yang benar mengenai perbedaan budaya itu sendiri maka dapat memicu konflik yang dapat memecah belah persatuan masyarakat.

Sebagai Kota multikultural yang memiliki jumlah pendatang sangat banyak, Malang pun telah mengalami berbagai peristiwa kelam akibat kurangnya kesadaran akan pentingnya memelihara perbedaan yang ada. Mulai dari konflik etnis Flores Maluku, Ternate - Sumba, Timor Leste Sumba dan masih banyak lagi konflikkonflik antar etnis yang lain yang hingga kini masih menimbulkan trauma yang mendalam serta stereotipe yang buruk di antara masyarakat masing-masing suku. Meskipun sesungguhnya konflik-konflik tersebut tidak bisa dikategorikan sebagai dominasi konflik karena sesungguhnya konflik yang terjadi hanyalah konflik antar etnis minoritas karena sesungguhnya dominasi etnis di Kota Malang tetaplah etnis Jawa. Peristiwa-peristiwa ini tentu mengindikasikan bahwa memang tidak mudah untuk dapat mengatasi kemajemukan yang ada dalam masyarakat, bahkan ekstrimnya ketidakmampuan mengelola kemajemukan ini berujung pada pertumpahan darah. Oleh karena itu, perbedaan budaya perlu diberi perhatian khusus, agar masyarakat yang ada didalamnya mampu hidup serasi dalam perbedaan yang ada.

Selain timbulnya konflik antar etnis, perbedaan budaya ini juga memunculkan permasalahan lain diantaranya munculnya permasalahan berkaitan dengan stereotype. Apalagi stereotype yang masih kuat berkembang dalam masyarakat mengenai karakter dari setiap budaya yang ada di Indonesia akan memperburuk proses interaksi untuk berkerja sama. Contohnya saja stereotipe mengenai orang Madura yang dianggap kasar, suka marah, curang, apabila terdapat dalam pemahaman salah seorang 
anggota masyarakat tentu individu tersebut akan cenderung membentengi diri untuk dapat melakukan interaksi secara lebih baik dengan individu lain yang berasal dari madura.

Berbagai macam kegiatan untuk menyatukan perbedaan budaya antar etnis yang dilakukan baik oleh pemerintah maupun organisasi sosial di Kota Malang telah banyak dilakukan, mulai dari dialog terbuka antar pemuka etnis yang diselaraskan dengan kegiatan keagamaan, pembangunan daerah tertinggal melalui program pemberdayaan masyarakat, sampai dengan pagelaran seni dan budaya antar etnis. Akan tetapi kegiatan semacam ini masih belum dilakukan dengan terintegrasi.Kegiatannya masih dilakukan secara internal di beberapa lembaga.

Di instansi pendidikan yang multicultural kegiatan untuk memberikan pemahaman etnis semacam ini sudah seringkali dilakukan. Universitas Merdeka Malang, salah satu Perguruan Tinggi swasta di Kota Malang yang memiliki mahasiswa yang multi etnis memiliki agenda tahunan berupa dialog antar etnis yang penyelenggaraannya dilakukan oleh Badan Eksekutif mahasiswa. Universitas Kanjuruhan Malang juga memiliki kegiatan serupa sebagai upaya untuk mengikis gesekan antar suku.

Penyelenggaraan event seperti ini dapat dilihat sebagai bentuk penerapan dari peran Public Relations (PR) sebagai teknisi yang mewakili sisi seni dan juga peran PR sebagai manajer. Dan Lattimore,dkk menjelaskan dua peran ini yaitu peran sebagai teknisi mewakili sisi seni dari public relations seperti menulis, mengedit, mengambil foto, menangani produksi komunikasi, membuat event spesial, dan melakukan kontak telepon dengan media. Kegiatan ini menitikberatkan pada implementasi strategi menyeluruh komunikasi. Sedangkan peran sebagai manajer berfokus pada kegiatan yang membantu organisasi dalam mengidentifikasi dan memecahkan masalah yang terkait dengan public relations (2010:62).

Kota Malang sebagai Kota Pendidikan yang memiliki keberagaman etnis di masyarakat tentunya mempunyai satu kewajiban untuk menciptakan pemahaman antar etnis guna menciptakan kehidupan bermasyarakat yang harmonis. Pendididkan multiculture harus menjadi prioritas kegiatan yang terelakkan. Masyarakat Malang sebagai salah satu public internal didalamnya berasal dari beragam latar 
belakang budaya yang ada di Indonesia. Keberagaman ini tentu saja dapat menimbulkan potensi perpecahan apabila setiap individu yang ada di dalamnya datang dengan stereotipe mengenai budaya lain sehingga mereka memberi jarak pada interaksi yang seharusnya memupuk kerja sama. Dalam hal inilah pihak Pemerintah Kota Malang yang terwakili oleh bagian Humas perlu untuk memberikan jembatan kepada masyarakat yang datang dari latar belakang budaya yang berbeda tersebut untuk dapat memahami dan menghargai setiap perbedaan budaya yang ada sehingga dapat terjalin interaksi yang menguntungkan diantara masyarakat sebagai publik internal Pemkot Malang.

Segala upaya yang dilakukan untuk menciptakan pemahaman budaya dalam publik internal guna menciptakan keselarasan dan kerjasama ini selanjutnya disebut Brand Internal Communications Culture (BICCU). BICCU menjadi satu kegiatan yang seharusnya dilakukan secara terintegrasi di bawah Humas Pemkot Malang. Dari kegiatan ini dapat dilihat bagaimana public relations berperan untuk dapat membetuk pemahaman multiculture communications pada public internal. Dalam penelitian ini penulis ingin mengungkap permasalahan tentang proses
Brand Internal Communication Culture (BICCU) dapat meningkatkan efektifitas Program Pendidikan Multiculture di Kota Malang.

\section{KERANGKA KONSEPTUAL \\ Ccorporate Image sebagai Pilar \\ Kesuksesan Organisasi}

Dalam bukunya The Company Image, Elinor Selame mengatakan identitas korporat atau corporate identity adalah apa yang senyatanya ada pada atau ditampilkan oleh perusahaan. (Sutojo, 2004:13 )

Identitas korporat bagi Anggoro (2008:280) adalah suatu cara atau suatu hal yang memungkinkan suatu perusahaan dikenal dan dibedakan dari perusahaanperusahaan lainnya. Ia juga menyebutkan bahwa identitas perusahaan harus diciptakan melalui suatu rancangan desain khusus yang meliputi hal-hal unik atau khas tentang perusahaan yang bersangkutan secara fisik.

Menrut Kasali, bahwa identitas perusahaan atau identitas korporat disebut juga sebagai simbol perusahaan, apakah berbentuk logo perusahaan atau lambang lainnya. Simbol selain dimaksud agar lebih mudah diingat oleh konsumen juga agar dijiwai oleh segenap karyawannya. Simbol sangat penting bagi perusahaan yang 
bergerak di sektor jasa yang menjaga pelayanan, kredibilitas, dan keramahan manusia di dalamnya (2003:110-114).

1. Elemen Corporate Identity Gregory dalam Sutojo (2004:14) menyatakan identitas korporat atau corporate identity terdiri dari dua elemen pokok, yaitu: nama (name/mark) dan logo (logos).

Anggoro (2000:280) menyatakan elemen-elemen utama identitas perusahaan atau identitas korporat meliputi tipe logo, warna/bentuk bangunan, atribut, sampai dengan seragam dan pakaian resmi perusahaan.

2. Mengefektifkan Corporate Identity Brannan (2004:79-80) mengatakan bahwa identitas perusahaan dapat memelihara prospek seperti diharapkan suatu perusahaan. Logo dan tipografi dirancang untuk meraih prospek tersebut. Desainnya membuat perusahaan kecil tampak besar. Sebuah desain yang baik adalah yang memberikan ruang dalam rancangannya dan desain tersebut akan lebih tampak menyerupai perusahaan yang sudah mapan.
Seperti yang dikemukakan Anggoro (2000:291) tentang identitas korporat yang mengatakan bahwa tipe, bentuk, warna-warna logo ternyata dapat melambangkan nilai, kebudayaan, sikap dan perilaku dari sebuah organisasi. Tipe logo dapat memunculkan identitas, dan akan mempersonifikasikan (membentuk sosok tertentu atas suatu lembaga atau perusahaan.

Shimp berpendapat (2003:307) bahwa strategi terbaik untuk meningkatkan kemampuan memuaskan diri dari suatu logo adalah dengan memilih suatu desain secara moderat cukup teliti menampilkan lebih dari sekedar gambar yang terlalu simple atau terlalu kompleks. Selain itu, desain-desain natural juga diperlukan untuk menghasilkan respons-respons konsumen yang lebih menguntungkan.

Logo merupakan sebuah simbol yang dirancang untuk mewakili karakter dan menjadi identitas dari sebuah perusahaan. Logo merupakan bentuk ekspresi dan bentuk visual dari konsepsi perusahaan, produk, organisasi, maupun institusi serta merupakan simbol visual yang memiliki bentuk yang berasal dari nilai strategis perusahaan. Pengertian logo menurut Jefkins, (1995:367) Logo adalah presentasi, sosok atau penampilan visual yang senantiasa dikaitkan dengan organisasi 
tertentu sebagai bentuk identitas dan bagian identitas perusahaan". Sebagai bagian identitas perusahaan, logo ibarat bagian tubuh yang mampu mengutarakan isi hati produk atau perusahaan.

Dari sisi pemasaran, logo mempunyai fungsi pembeda produk dengan produk lainnya. Menurut pakar corporate identity David E. Carter dalam Kusrianto (2007) setidaknya logo perusahaan harus memiliki karakter tertentu, menyangkut : Original dan Destinctive, Legible,Simple, Memorable, Easly associated with the company, dan Easly adaptable for all grhapic media yang mudah di aplikasikan ke berbagai media, untuk menghindari kesulitan dalam penerapan. Elemen-elemen dalam komunikasi visual suatu logo, antara lain bentuk, warna dan tipografi.

Dengan demikian logo yang telah memenuhi persyaratan untuk penampilan fisik saja tidak cukup, karena logo bukanlah hanya menyangkut penampilan visual saja, melainkan sebuah logo haruslah memiliki makna dan tujuan yang terkandung didalamnya.

\section{Manajemen Konflik Antar Budaya}

Penyelesaian konflik memiliki pola yang berbeda pada setiap budaya. Masyarakat Jepang misalnya lebih suka untuk menghindari konflik untuk menjaga keharmonisan sosial, berbeda dengan di Amerika yang lebih mengutamakan kepentingan pribadi. Dari hasil penelitian dengan judul yang berbeda Lestari (2015) dan Rejeki (2015) senada menghasilkan pendapat tentang acuan untuk penyelaesaian konflik antar budaya, yaitu :

1. Identifikasi Isu yang Mengakibatkan Masalah

Mengidentifikasi inti permasalahan merupakan hal yang penting untuk dapat memfokuskan setiap pihak yang terlibat dalam masalah tersebut pada upaya untuk mencari solusi.

2. Jaga Pikiran untuk Tetap Terbuka Setiap konflik yang dialami harus dapat ditanggapi dengan "pikiran terbuka". Hal ini dimaksudkan agar seseorang dapat melihat konflik yang terjadi dari sudut pandang orang lain tanpa kehilangan prinsip yang juga harus menjadi pegangannya.

\section{Jangan Terburu-buru}

Seringkali karena terdesak oleh transaksi bisnis yang mahal (biaya penginapan, transportasi), seseorang sangat terburuburu dalam menyelesaikan konflik yang muncul, sehingga penyelesaiannya menjadi tidak mendalam. 
4. Jagalah Konflik agar Berpusat pada Ide bukan pada Orangnya

Pengkondisian memberikan keuntungan bahwa penyelesaian masalah hanya difokuskan pada bagaimana upaya mencari jalan keluar, dan bukan pada pertentangan untuk mempertahankan ego masing-masing.

\section{Internal Communications}

Morisan (2008:8) mengutip pendapat Cutlip-Center-Broom bahwa "Public Relations is the planned effort to influence opinion through good character and responsible performance, based on mutually satisfactory two-way communications."

Event yang merupakan salah satu media Public Relations memiliki peran bagi seorang Public Relations antara lain: untuk memberikan informasi secara langsung (bertatap muka) dan mendapatkan hubungan timbal balik positif dengan publiknya. Sebagai media komunikasi dan sekaligus untuk mendapatkan publikasi, dan pada akhirnya masyarakat atau public sebagai target sasaran akan memperoleh pengenalan, pengetahuan, pengertian yang mendalam dan diharapkan dari acara khusus tersebut dapat menciptakan citra positif terhadap perusahaan atau produk yang diwakilinya. (Ruslan, 2002:133)
Gudykunst (1992) berpendapat bahwa jika dua orang atau lebih berkomunikasi, antarbudaya secara efektif, maka mereka akan berurusan dengan satu atau lebih pesan yang ditukar (dikirim dan diterima); mereka harus bisa memberikan makna yang sama atas pesan. Singkat kata, komunikasi yang efektif adalah komunkasi yang dihasilkan oleh kemampuan para partisipan komunikasi lantaranmereka berhasil menekan sekecil mungkin kesalahpahaman (Liliweri, 2007:227).

Komunikasi internal merupakan bentuk interaksi yang dilakukan dengan pihak-pihak internal suatu organisasi. Komunikasi internal yang berjalan efektif akan meningkatkan kualitas kerja dari karyawan yang ada didalamya sehingga sasaransasaran organisasi dapat tercapai. Untuk membangun komunikasi internal yang efektif dapat dilakukan melalui kegiatankegiatan seperti berikut (Cutlip, 2011: 269)

1. Pernyataan Visi

Pernyataan visi merupakan salah satu bentuk atau cara organisasi menyampaikan tujuan atau sasaran-sasaran organisasi tersebut kepada setipa publik internalnya.

2. Dokumen Kebijakan 
Dokumen kebijakan umumnya berisikan prosedur-prosedur yang harus dilakukan oleh anggota organisasi untuk mengajukan hal-hal umum yang tidak sesuai dengan standar yang telah ditetapkan.

3. Materi Training

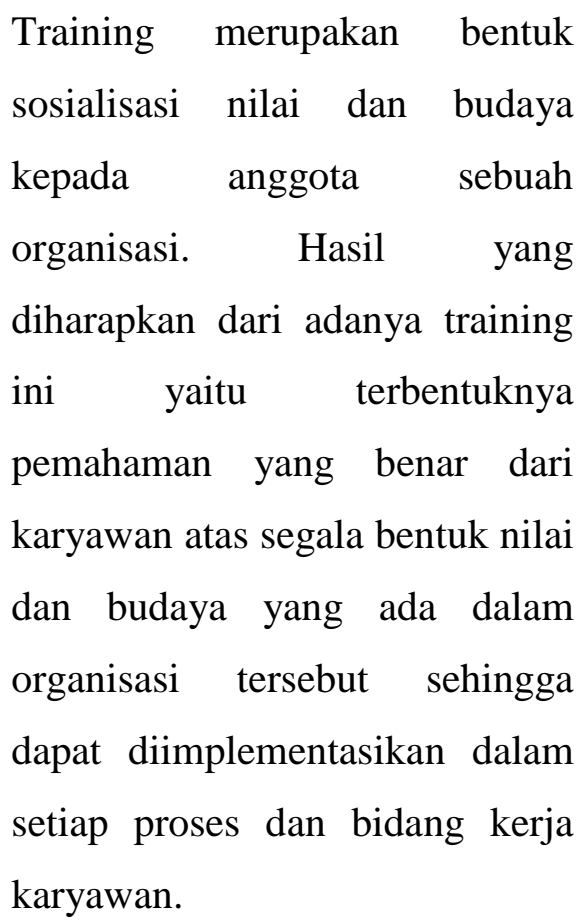

Menurut Kotler (1997:8) pemasaran adalah suatu proses sosial dan manajerial yang didalamnya individu atau kelompok mendapatkan apa yang mereka butuhkan dan inginkan dengan menciptakan, menawarkan, dan mempertukarkan produk yang bernilai dengan pihak lain.

\section{METODE PENELITIAN}

Dalam penelitian ini merupakan penelitian dengan pendekatan subyektif. Penelitian jenis penelitian deskriptif kualitatif. Penelitian ini menggambarkan realitas yang sedang terjadi tanpa menjelaskan hubungan antar variabel. Disamping itu penelitian ini menekankan pada karakteristik atau ciri individu, situasi serta kondisi kelompok tertentu (Ruslan, 2008:12)

Adapun yang menjadi fokus pada penelitian ini yaitu

1. Proses interaksi dalam nuansa perbedaan budaya

2. Kualitas interaksi antar individu yang berbeda budaya

3. Kegiatan BICCU sebagai salah satu media PR untuk meningkatkan brand kota Malang sebagai Kota multikultural.

Yang menjadi informan pada penelitian ini yaitu:

a. Humas Pemerintah Kota Malang, sebagai pelopor terciptanya kegiatan BICCU sehingga dapat diperoleh informasi mengenai apa harapan dari diadakannya kegiatan ini dan bagaimana kegiatan ini mmpu meningkatkan pendidikan multicultural di masyarakat Kota Malang.

b. Anggota masyarakat dengan asal daerah yang berbeda-beda. Hal ini untuk dapat mengetahui apakah ada kesulitan untuk 
dapat menyesuaikan diri dengan lingkungan yang baru dan bagaimana kualitas ineraksi diantara masyarakat yang berbeda budaya tersebut. Adapun kerangka konseptualnya sebagi berikut :

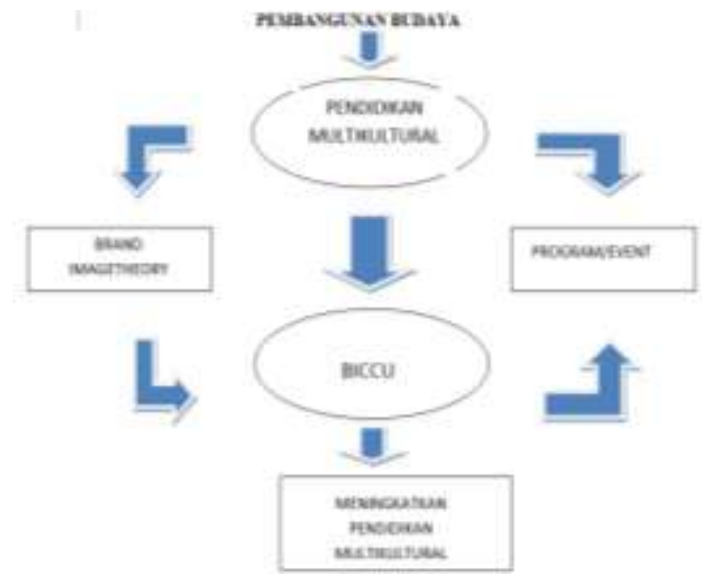

\section{PEMBAHASAN}

Penelitian ini menjadikan enam informan sebagai sumber informasi utama untuk melihat bagaimana BICCU bisa diterapkan di Kota Malang melalui instansi. Humas Pemkot Malang menjadi ujung tombak atas keberhasilan program tersebut. Sebab, hal ini menyangkut dengan city branding atau citra dari Kota Malang. Berdasarkan hasil wawancara terhadap enam orang informan maka berikut pembahasannya.

Dalam penelitian ini peneliti mengajukan 10 pertanyaan yang dijadikan sebagai instumen dalam pengumpulan data. Dari 10 pertanyaan tersebut enam informan memiliki kecenderungan kesamaan dalam menjawab pertanyaan tersebut.

Hal ini terlihat dari jawaban atas pertanyaan gambaran multi etnis yang ada di kota Malang. Dari lima orang informan anggota masyarakat dan satu perwakilan humas pemkot mengatakan bahwa multi etnis di Kota Malang sangat bervariasi. Hal ini disebabkan karena Malang sebagai Kota Pendidikan mengakibatkan banyak sekali masyarakat dari luar Malang yang datang ke Malang untuk menempuh pendidikan. Para pelajar/mahasiswa ini datang dengan membawa karakter masing-masing. Informan 1 menjawab dengan jawaban yang lebih keras. Menurutnya datangnya pelajar/mahasiswa yang datang dari berbagai pelosok nusantara ini seringkali menyebabkan kesalahpahaman bahkan sampai terjadi pertengkaran ataupun pertikaian. Senada dengan informan 1 (anggota masyarakat), informan 5 (anggota masyarakat) juga memiliki pendapat serupa. Menurutnya seringnya terjadi pertikaian antar mahasiswa menyebabkan nama baik Kota Malang menjadi tercemar. Malang tidak lagi menjadi kota bunga yang ramah dan damai tetapi menjadi kota yang jauh dari Kota Malang terdahulu. Dari 
keseluruhan informan semuanya sepakat bahwa Malang kini menjadi global sehingga representasi masyarakat Indonesia.

Selain itu, dampak yang mungkin muncul akibat multi etnis informan bersepakat berpendapat bahwa multi etnis sangat berkaitan erat dengan perselisihan dan pertengkaran. Multietnis juga sangat rentan terhadap munculnya justifikasi pelebelan negatif (stereotype) terhadap etrnis tertentu di masyarakat. Apalagi jika pendatang tersebut memiliki teman yang banyak yang sama-sama merantau di Malang. Mereka cenderung untuk mengurangi sosialisasi bersama masyarakat sekitar dan seolah menciptakan kelompok sendiri dan melakukan segala sesuatu seolah mereka tidak sedang berada di kota orang lain yang memiliki budaya dan kebiasaan berbeda. Sementara informan 2 dan 3 (anggota masyarakat) memiliki jawaban yang sedikit lebih terbuka. Mereka mengatakan bahwa keberadaan masyarakat dari wilayah lain akan berdampak pada dua hal positif dan negatif. Dampak negatif seperti perselisihan paham dan pertengkaran akan muncul jika keberadaan mereka tidak saling disadari sebagai masyarakat yang memiliki budaya dan kebiasaan berbeda. Egosentris masing-masing etnis akan menyebabkan masing-masing kelompok etnis merasa bahwa budaya dan kebiasaan mereka adalah yang terbaik. Sebaliknya jika keberagaman etnis ini dianggap sebagai satu kekuatan luar biasa yang dapat digunakan untuk memperkaya khasanah budaya yang dimiliki oleh Kota Malang maka multi etnis dapat digunakan sebagai sarana pemersatu dan bias menjadi sebuah cara untuk dapat saling menghormati dan menghargai satu dengan yang lain.

Dari pengetahuan seluruh informan mereka mengatakan bahwa mereka mengetahui konflik antar etnik pernah beberapa kali terjadi di Kota Malang. Konflik antar etnis ini seringkali muncul di kalangan kelompok mahasiswa yang tinggal di beberapa lokasi yang berdekatan dengan kampus sebuah perguruan tinggi. Konflik seperti ini sudah lebih dari 5 kali terjadi dalam satu tahun baik yang berskala besar maupun perseorangan. Menurut para informan kejadian seperti ini betul-betul sudah mencoreng nama baik Kota Malang. Informan 4 (anggota masyarakta) mengatakan bahwa seharusnya pemerintah Kota Malang harus ekstra waspada terhadap kejadian-kejadian seperti ini, karena masyarakat sudah merasa resah dengan keberadaan beberapa kelompok etnis teretentu. Bahkan di beberapa wilayah di Kota Malang sudah menolak keberadaan 
mereka untuk tinggal dan menyewa rumah mereka.

Terkait peristiwa yang terjadi di atas, informan humas pemkot Malang mengatakan bahwa ada banyak hal yang sudah dilakukan pemkot dalam menghalau konflik etnis yang timbul. Peran utama justru ada pada masyarakat yang hidup dalam perbedaan budaya itu sendiri. Dari pemerintah kota sellau mengupayakan sosialisasi yang sifatnya mempersatukan warga. Dengan ditanyai konsep BICCU humas kota Malang tertarik dengan konsep tersebut dengan menyetujui pendekatan humanis yang menyetuh individu dan kelompok tanpa ada diskriminasi.

Perwakilan anggota masyarakat mengatakan bahwa kegiatan BICCU harus segera dilakukan mengingat jumlah pendatang dari luar daerah ke Kota Malang makin meningkat dari tahun ke tahun. Selain itu gesekan budaya yang terjadi di masyarakat juga mengalami peningkatan kuantitas. Sehingga pendidikan multicultural sangat mendesak untuk dilakukan.Informan 4 mengatakan konsep pendidikan multicultural tidak harus diberikan secara kaku dan sangat formal. Pendidikan multicultural dapat diberikan dengan menggunakan konsep yang lebih santai dan menyenangkan yang penting masyarakat akan menyadari bahwa keberadaan kelompok masyarakat lain yang ada di Kota Malang sebagai satu kekayaan budaya yang patut untuk disyukuri dan dikembangkan menjadi potensi luar biasa bagi Pemerintah Kota Malang.

Ketika peneliti menanyakan konsep BICCU kepada informan anggota masyarakat, mengatakan patut dicoba untuk menumbuhakn kesadaran etnis masyarakat agar tidak tejadi diskriminasi lagi. Komunikasi internal merupakan strategi yang dianggap dekat dengan masyarakat. Sebab, komunikasi internal sudah menjadi bagian dari kehidupan mereka sehari-hari. Seperti misalnya mereka melakukan perkumpulan atau rapat yang melibatkan pendatang. Dengan demikian diskriminasi dan pelabelan negatif bisa dihindarkan.

Memberikan pemahaman dalam konsep BICCU tidak melalui aksi kekerasan, melainkan lebih menekankan asas kemanusiaan dan toleransi. Meskipun komunikasi internal biasanya dilakukan hanya di perusahaan, struktur masyarakat juga bisa menerapkan komunikasi internal. Karena pada dasarnya komunikasi internal merupakan tindakan dasar yang setap 
manusia selalu melakukannya di lingkungan mereka.

Pemerintah Kota Malang melalui Humas berharap dapat menggandeng seluruh perguruan tinggi di Kota Malang untuk bisa melakukan program kegiatan yang berlandaskan konsep BICCU. Humas berpendapat bahwa akar dari multikultural ada pada perguruan tinggi. Hal tersebut akan dinilai masif untuk membantu merumuskan bentuk kegiatan serta realisasi program tersebut.

Sehubungan dengan hal tersebut, BICCU dinilai sebagai konsep yang mudah diterima dan dipahami oleh masyarakat manapun. Perbedaan budaya bukan lagi untuk didiskriminasikan atau dipertentangkan. Melalui BICCU perbedaan budaya dikomunikasikan menjadi unsur komunikasi yang dapat mewarnai pola komunikasi antar budaya yang ada di Kota Malang.

\section{PENUTUP}

\section{Kesimpulan}

Kesimpulan dari tulisan ini adalah sebagai berikut :

1. Perbedaan budaya di Kota merupakan aset pemerintah kota untuk bisa menjalin komunikasi antar budaya yang lebih masif.

2. Konsep BICCU sesuai dengan geografi dan demografi Kota Malang. Masyarakat Malang menginginkan konsep baru yang dapat mewarnai perbedaan budaya di antara mereka.

3. Logo atau brand BICCU mampu mengikat perbedaaan budaya yang terjadi di Kota Malang.

4. Komunikasi antar budaya yang dilakukan dengan menekankan asasa komunikasi internal meminimalisir konflik antar etnis

\section{Saran}

Dari kesimpulan di atas, penulis merekomendasikan saran sebagai berikut :

1. Konsep BICCU dapat diturunkan menjadi kegiatan kreatif yang melibatkan masyarakat yang disesuaikan dengan kondisi masingmasing daerah di Kota Malang.

2. Stakeholder merupakan komponen penting dalam konsep BICCU. Karena perbedaan budaya membutuhkan perantara atau dalam komuniasi sering disebut sebagai gate keeper. Sehingga dalam 
implementasinya pemerintah kota menggandeng stakeholder.

\section{REFERENSI}

Anggoro, Linggar M, 2008, Teori dan Profesi Kehumasan serta Aplikasinya di Indonesia, Bumi Aksara, Jakarta.

A. Shimp, Terence. 2003. Periklanan Promosi. Erlangga, Jakarta.

Brannan, Tom. (2004). Integrated Marketing Communications. Memadukan Upaya Publik Relations, Iklan dan Promosi untuk membangun identitas merek. PPM, Jakarta.

Cutlip, Scott M, Center, Allen H, Broom, Glend M, 2011, Effektive Public Relations, Kencana, Jakarta.

Gudykunst, Willian B, Kim, Young Yun, 1992, Communicating With Strangers : An Aprroach, to Intercultural Communications. McGraw-Hill, New York.

Jefkins, Frank. 1995. Periklanan. Erlangga. Jakarta.

Kasali, R. 2003. Manajemen Public Relations. Jakarta, Grafiti.

Kotler, Philip. 1997. Manajemen Pemasaran. Prenhallindo, Jakarta.

Kusrianto, Adi. 2007. Pengantar Desain Komunikasi Visual. Andi Offset, Jakarta.
Lattimore, Dan, et al, 2001, Public Relations-The Profession and The Practice, Salemba Humanika, Jakarta.

Liliweri, Alo, 2007, Makna Budaya dalam Komunikasi Antar Budaya, LKiS, Yogyakarta.

Morissan, 2010, Manajemen Public Relations. Kencana, JakartaSutojo, Siswanto. 2004. Membangun Citra Perusahaan. Jakarta: Damar Mulia Pustaka

Rosady Ruslan. Manajemen dan Komunikasi, Konsep dan Aplikasi. 2002. PT Raja Grafindo Persada, Jakarta.

Ruslan, Rosady, 2008, Metode Penelitian $P R$ dan Komunikasi. Rajawali Pers, Jakarta.

Sumber Lain :

Lestari, Puji. Stereotipe dan Kompetensi Komunikasi Bisnis Antarbudaya Bali dan China.

http://jurnal.uajy.ac.id/jik/files/2012/ 05/4.Puji-Lestari-41-72.pdf. Diakses 17 Agustus 2013.

Rejeki, Sri Ninik. Perbedaan Budaya dan Adaptasi Antar Budaya dalam Relasi Kemitraan Inti Plasma. http://jurnal.uajy.ac.id/jik/files/2012/ 05/3.-MC-Ninik-Sri-rejeki-145166.pdf. Diakses 17 Agustus 2013. 